Kocaeli Üniversitesi Sağlık Bilimleri Dergisi

\title{
SPONTANEOUS PERFORATION OF POLYVINYL ALCOHOL MEMBRANE: A RARE CAUSE OF ATRIAL SEPTAL OCCLUDER FAILURE
}

\author{
POLIVINIL ALKOL MEMBRANININ SPONTAN PERFORASYONU: \\ ATRIYYAL SEPTAL DEFEKT KAPAMA CIHAZI DISFONKSIYYNUNUN NADIR BIR NEDENI
}

\author{
DHakan Parlar ${ }^{1} @$ (Derdar Bozyel ${ }^{2 *}$
}

${ }^{1}$ Health Sciences University, Derince Training and Research Hospital, Department of Cardiovasular Surgery, Kocaeli, Turkey.

${ }^{2}$ Health Sciences University, Derince Training and Research Hospital, Department of Cardiology, Kocaeli, Turkey

ORCID iD: Hakan Parlar: 0000-0003-0982-9766; Serdar Bozyel: 0000-0002-6582-3660

*Corresponding Author / Sorumlu Yazar: Serdar Bozyel, e-mail / e-posta: drserdarbozyel@ gmail.com

Received / Geliş Tarihi: 05.08.2019 Accepted / Kabul Tarihi: 29.08.2019

Published / Yayım Tarihi: 06.09.2019

\begin{abstract}
Objective: Percutaneous closure of atrial septal defect is a well-established procedure and has evolved to become the standard of care due to its many advantages. However, atrial septal defect closure devices covered with polyvinyl alcohol membrane could cause recurrent significant shunts due to a spontaneous polyvinyl alcohol membrane perforation. To investigate whether spontaneous polyvinyl alcohol membrane perforation developed in our patients who had implanted with CARDIA Ultrasept atrial septal defect occluder (Eagan, Minnesota, USA) that covered with Polyvinyl Alcohol membrane.

Methods: We retrospectively rewieved all patients with a diagnosis of secundum type atrial septal defect who underwent percutanoues closure with CARDIA Ultrasept prosthesis.

Results: Ten patients aged 4 to 56 years who underwent atrial septal defect closure with UItrasept device were included. During a median 26 months follow up period, we detected a four cases of polyvinyl alcohol membrane failure. In 3 patients, perforation of polyvinyl alcohol membrane caused significant left to right shunt that required re-intervention, while in one patient it caused minimal residual shunt. The devices were used were $14 \mathrm{~mm}$ (two patients), $16 \mathrm{~mm}$ (one patient) and $30 \mathrm{~mm}$ (one patient). Two patients underwent surgical device removal and pericardial patch closure. One patient underwent device in device procedure. Residual shunts were not occured in after reinterventions.

Conclusion: Polyvinyl alcohol membrane perforation is rare and can require reintervention. Operators have to be aware of this malfunction.
\end{abstract}

Keywords: Polyvinyl alcohol membrane, perforation, atrial septal defect occluder, recurrent shunt

\section{$\ddot{O} z$}

Amaç: Atriyal septal defektin perkütan yolla kapatılması etkinliği kanıtlanmış bir prosedür olup birçok avantajı nedeniyle standart tedavi haline gelmiştir. Bununla birlikte, polivinil alkol membran ile kaplanmış Atriyal septal defektin kapama cihazları, spontan Polivinil Alkol membran perforasyonuna bağlı olarak tekrarlayan ciddi şantlara neden olabilir. Çalışmamızda, Polivinil Alkol membran ile kaplı CARDIA Ultrasept Atriyal septal defektin kapama cihazı (Eagan, Minnesota, ABD) implante edilen hastalarımızda, spontan polivinil alkol membran perforasyonu gelişip gelişmediğini araştırmayı amaçladık.

Yöntem: CARDIA Ultrasept protezi ile perkütan kapama uygulanan sekundum tip Atriyal septal defektin tanılı tüm hastalarımızı retrospektif olarak gözden geçirdik.

Bulgular: UItrasept cihazı ile atriyal septal defektin kapama işlemi uygulanan, 4 ila 56 yaşları arasında olan on hasta çalışmaya alındı. Medyan 26 aylık takip periyodu sırasında, dört hastada polivinil alkol membran sorunu saptandı. Üç hastada polivinil alkol membran perforasyonu tekrar girişim gerektiren ciddi soldan sağa şanta neden olurken, bir hastada minimal rezidü şanta neden oldu. Kullanılan cihazlar 14 mm (iki hasta), 16 mm (bir hasta) ve $30 \mathrm{~mm}$ (bir hasta) idi. İki hastada, sorunlu cihazın cerrahi olarak çıkarılması ve perikardiyal yama ile kapama işlemi uygulandı. Bir hastada ise perkütan ikinci atriyal septal defektin cihazı ile kapama işlemi uygulandı. İkinci prosedürler sonrası, bu üç hastada da rezidü şant tespit edilmedi. Sonuç: Polivinil alkol membran perforasyonu nadir görülür ve genellikle yeniden girişim gerektirir. Operatörler bu sorunun farkında olmalı ve polivinil alkol membran kaplı cihaz implante edilen tüm hastalarını tekrar gözden geçirmelidirler.

Anahtar Kelimeler: Polivinil alkol membran, perforasyon, atriyal septal defekt kapama cihazı, rekürren şant 


\section{Introduction}

Percutaneous ASD closure has evolved to become the preferred strategy because of its certain advantages, including avoidance of sternotomy, a lower incidence of procedural complications, and an early discharge. ${ }^{1,2}$

Since the first successful ASD closure with a device, a great deal improvements have been made and some devices have been developed in closure device technology. ${ }^{2}$ One of them is CARDIA ASD prostheses (Eagan, Minnesota, USA), which have been available since 1998 and advanced several generations. The latter versions were named Atriasept I/II and afterwards the Ultrasept I/II. In order to minimise device material and improve flexibility, all Cardia devices are made of two low-profile nitinol disc frames covered with PVA membrane which is a water-soluble polymer, can become insoluble for certain medical purposes. ${ }^{4}$ The devices, with a patented self-centring mechanism, have both retrievable and repositionable features. ${ }^{5,6}$ However, It has been revealed that the CARDIA ASD prostheses show multiple PVA membrane perforations from 1 week to 24 months following postimplantation. ${ }^{7-12}$ This malfunction was found independent from device size and noticed in the last two generations.

The purpose of the study was to investigate retrospectively all ASD patients with CARDIA Ultrasept ASD occluder (an older version of the Ultrasept II) in our centre and examine whether spontaneous PVA membrane perforation developed in the long term.

\section{Methods}

This is a retrospective study consisted of a total of 10 patients with a diagnosis of secundum type ASD who underwent ASD closure with CARDIA Ultrasept prosthesis at our centre.

\section{Preoperative Assessment}

Patients' suitability for procedure were assessed by transthoracic and transesophageal echocardiography (TTE/TEE). ASD number, size, position and rims were appraised. The largest size of defect was accepted as reference diameter. Cardiac dimensions, ventricular functions and valves were also assessed.

\section{Implantation Procedure}

The all procedures were performed under general anesthesia. The deployment and release steps were done under fluoroscopy and TEE guidance. After releasing the device, a final TEE examination was undertaken to show the position of the device and any residual shunting.

\section{Follow-up}

Patients were discharged one day after the procedure with 100 $\mathrm{mg}$ aspirin and clopidogrel $75 \mathrm{mg}$. The follow-up was conducted by clinical evaluations, electrocardiography and transthoracic echocardiography at day 1 , at 1,6 , and 12 months, then yearly thereafter. All patients underwent TTE during each visit. If a suspicious shunt was detected in the patient's echocardiography, then the measurements also performed by different operator and the finally, three dimensional TEE was performed.

Written informed consent was obtained from all patients.

\section{Statistical Analysis}

Statistical analysis was performed with IBM SPSS 20.0 (IBM Corp., Armonk, NY, USA) package program. Continuous variables were expressed as means \pm standard deviations, and categorical variables were expressed as numbers and percentages.

\section{Results}

Ten patients who underwent ASD closure with UItrasept device were included in the analysis. This group included 7 female patients $(70 \%)$ aged 4 to 56 years, with median age 31 . The devices used were $14 \mathrm{~mm}$ (two patients), $16 \mathrm{~mm}$ (three patients), $20 \mathrm{~mm}$ (four patients), $30 \mathrm{~mm}$ (one patient). All devices were placed successfully.

During a median 26 months (range 13-44 months) follow up period, we detected four PVA membrane failure cases. All of them were female aged 4 to 54 years, with mean age 32.2. Minimal residual shunt was detected in one patient in the $3 \mathrm{rd}$ month following the operation and there was no progress in residual shunt in the 31 st month of follow-up. While minimal shunt was detected in one patient in the 9th month, the shunt was observed to progress significantly in the 25th month during regular follow-up. Severe shunt development was determined in remaining two patients during 19th and 34th months.

In three patients, PVA membrane failure caused significant shunt through the central portion of the devices that required re-intervention (Figure 1A, B, C) while in one patient it caused only minimal residual shunt. 3 of these patients were asymptomatic and the diagnosis was made during regular polyclinic follow-up. Case-2 was diagnosed by routine examination performed in her admission with unstable angina pectoris. The devices used were $14 \mathrm{~mm}$ (two patients), $16 \mathrm{~mm}$ (one patient) and $30 \mathrm{~mm}$ (one patient).

Percutaneous or surgical re-intervention was decided upon detection of severe recurrent shunting. No other measurements were made. Case 2 and 3 were underwent surgical failing device removal and patch closure. Since the case- 2 had a serious coronary artery disease, device removal and ASD closure were performed together with coronary artery bypass graft surgery. On perioperative view, the device appeared correctly implanted, frames were intact and PVA membrane around the frame almost totally disappeared with incomplete endothelialisation (Figure 2 A, B). Case-4 underwent device in device procedure in another centre. Amplatzer ASD Occluder was used as a second device. Residual shunts were not detected in these three patients after reintervenion. A close follow-up was planned for patients with minimal residual shunt. Baseline patient characteristics, review of diagnosis and management of device malfunctions were shown in the Table 1. 


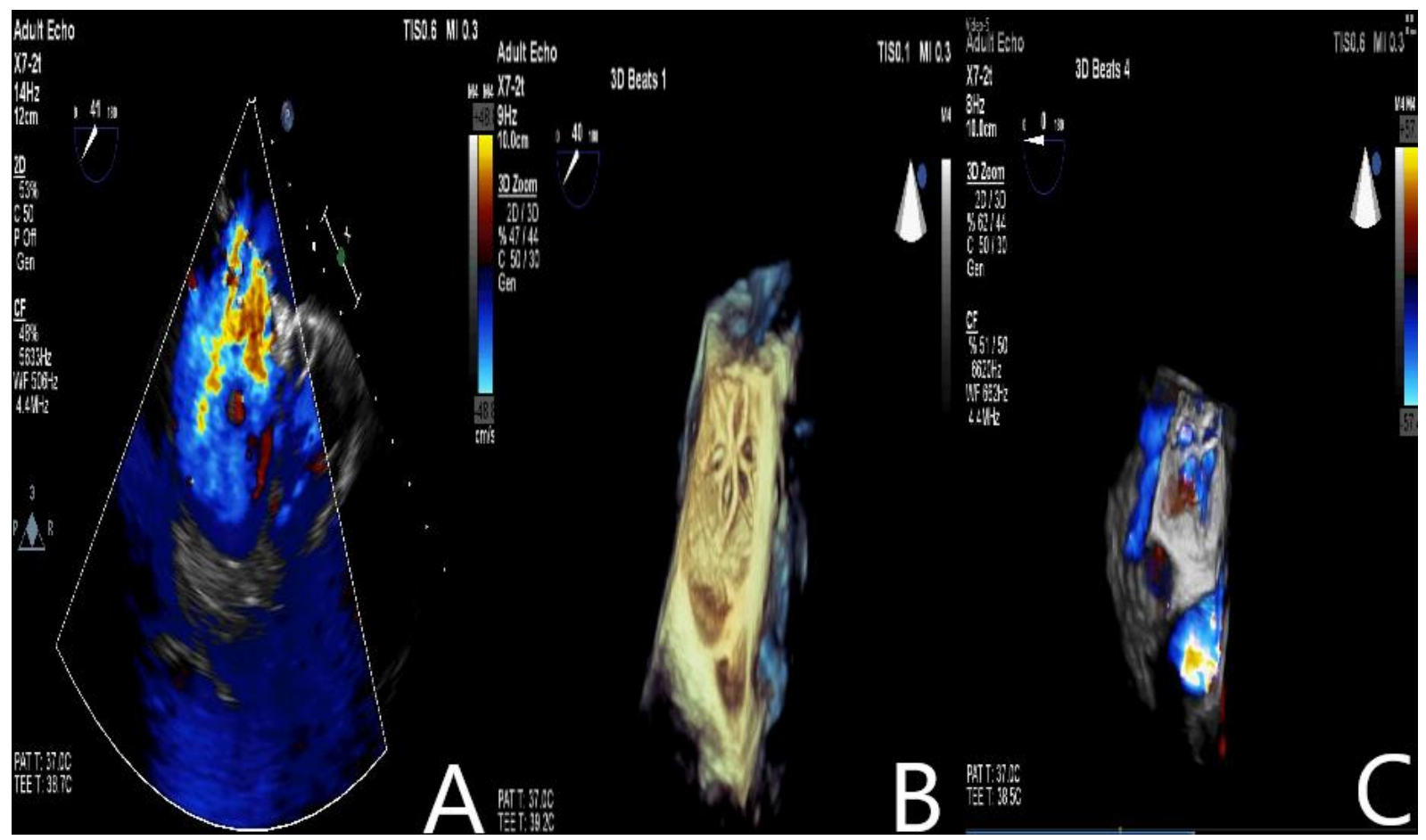

Figure 1. Two dimensional (2D) transesophageal echocardiography (TEE) demonstrated significant left to right shunt through the central portion of the prosthesis (1A). Three dimensional (3D) TEE showed a multiple perforations on PVA membrane with intact image of nitinol frame (1B) and 3D color doppler imaging showed significant shunt through the central portion of the device (1C).

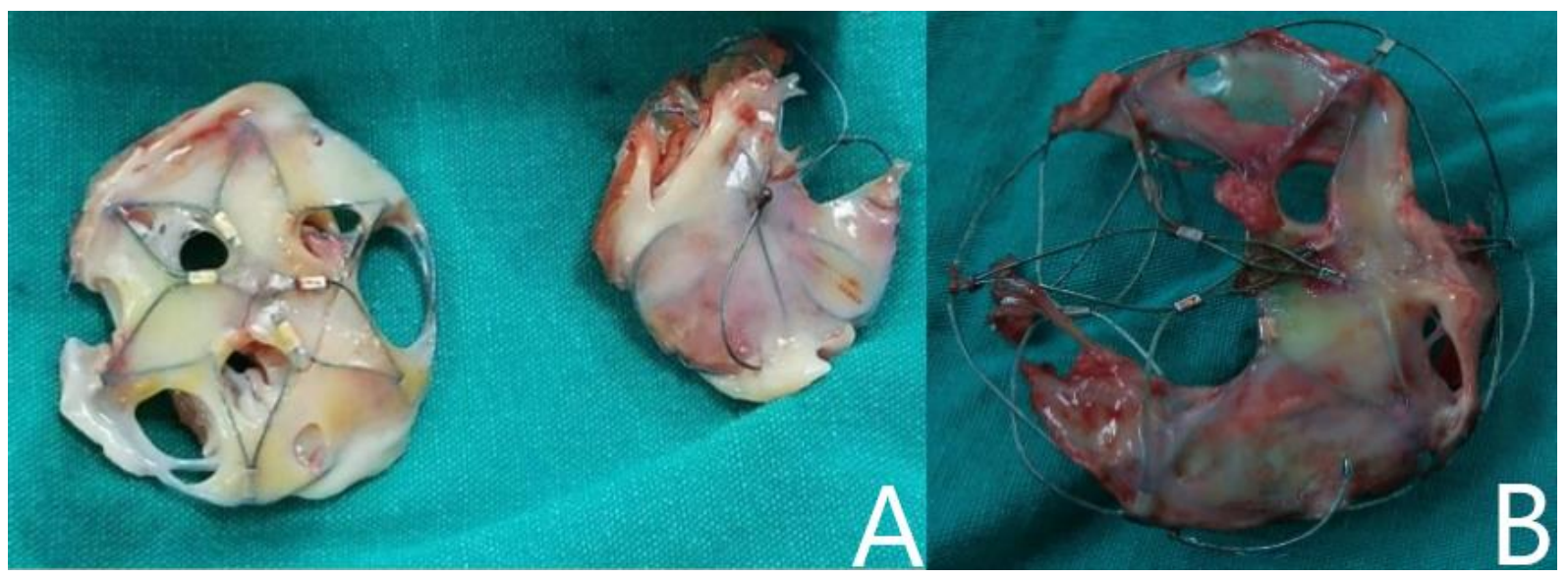

Figure 2. Perioperative view showing incomplete endothelialization around the intact frame in both right and left of the disc of the device (2A). Another view showing totally disappeared PVA membrane with incomplete endothelialization around the intact frame (2B).

Table 1. Baseline patient characteristics, review of diagnosis and management of device malfunction

\begin{tabular}{|c|c|c|c|c|c|c|c|}
\hline Cases & $\begin{array}{l}\text { Age, } \\
\text { Gender }\end{array}$ & $\begin{array}{l}\text { Defect/Device } \\
\text { size }(\mathbf{m m})\end{array}$ & Comorbidities & $\begin{array}{l}\text { Recurrence time and } \\
\text { degree of shunt after the } \\
\text { procedure }\end{array}$ & Symptom & Management & $\begin{array}{l}\text { Follow -up } \\
\text { (months) }\end{array}$ \\
\hline Case 1 & $4, \mathrm{~F}$ & $13 / 14$ & None & $\begin{array}{l}3 \text { months-minimal residual } \\
\text { shunt }\end{array}$ & No & Follow-up & 31 \\
\hline Case 2 & $54, \mathrm{~F}$ & $27 / 30$ & CAD & $\begin{array}{l}9 \text { months-minimal residual } \\
\text { shunt } \\
25 \text { months-significant } \\
\text { residual shunt }\end{array}$ & No & $\begin{array}{l}\text { Surgical device removal } \\
\text { and pericardial patch repair }\end{array}$ & 44 \\
\hline Case 3 & $41, \mathrm{~F}$ & $16 / 16$ & None & $\begin{array}{l}34 \text { months-significant } \\
\text { residual shunt }\end{array}$ & No & $\begin{array}{l}\text { Surgical device removal } \\
\text { and pericardial patch repair }\end{array}$ & 36 \\
\hline Case 4 & $30, \mathrm{~F}$ & $14 / 14$ & None & $\begin{array}{l}19 \text { months-significant } \\
\text { residual shunt }\end{array}$ & No & Device in device technique & 21 \\
\hline Case 5 & $44, \mathrm{M}$ & $18 / 20$ & None & None & - & - & 15 \\
\hline Case 6 & $32, \mathrm{~F}$ & $14 / 16$ & None & None & - & - & 13 \\
\hline Case 7 & $6, \mathrm{~F}$ & $16 / 16$ & None & None & - & - & 34 \\
\hline Case 8 & $13, \mathrm{M}$ & $18 / 20$ & None & None & - & - & 40 \\
\hline Case 9 & $26, \mathrm{M}$ & $18 / 20$ & None & None & - & - & 34 \\
\hline Case 10 & $56, \mathrm{~F}$ & $16 / 20$ & None & None & - & - & 19 \\
\hline
\end{tabular}




\section{Discussion}

Ultrasept ASD Occluder has a double round nitinol disc covered with PVA membrane which is frequently used in medical devices due to its chemical resistance, biocompatibility and high water solubility. It is stated that PVA can decrease the risk of thrombus formation and enhance more homogeneous endothelialisation. ${ }^{1,2}$ However, it has been reported in several publications that PVA membrane with many versions of the CARDIA ASD prostheses have early or delayed malfunctions. ${ }^{7-}$

12 Bartel et al reported two cases, including devices failure in patients treated with the Atriasept II (Cardia Inc, Eagan, MN), an older version of the device that we used. ${ }^{7}$ Bhattacharyya et al. also revealed disintegration of PVA with the same version device that we have. ${ }^{8}$ Besides, several cases of device failure were reported with Ultrasept II ASD occluders. ${ }^{9-11}$

PVA membrane disintegration mostly lead to significant recurrent shunts that reintervention was required. In most cases, surgical removal and pacth repair were advised. Covering the damaged membrane with a second device can be considered as an alternative to surgery. ${ }^{8-11}$ The space between the nitinol struts made it possible to cross the long sheath for implanting the second device. Chamié et al. applied 'device in device technique' to four patients and showed that implanting a second nitinol symmetrical double disk over the first one was technically feasible. As surgery has many risks and the patient preference is particularly considered, the second device technique can be performed. Similar to the Cardia ASD prosthesis, having the same low profile metal frame could help the second device achieve better apposition to the first. ${ }^{13}$ However, since the mechanism of PVA membrane disappearance is unknown, a second device with a different structure should be chosen to avoid recurrent inadequate endothelialization response ${ }^{8,11,14}$

ASD device sizes utilized in reported cases range from $14 \mathrm{~mm}$ to $30 \mathrm{~mm}$, so the complication seems to be independent from size. There was no evidence of infection or any failure mechanism. However, it is likely associated with early reabsorption of the PVA sail, related to late or incomplete endothelialization. This phenomenon has been reported with other ASD devices, supporting the hypothesis of an inadequate endothelization response, of unknown cause..$^{15,16}$

After 2015, manufacturer produced a new generation device Ultrasept II ${ }^{\mathrm{TM}}$ - where a Goretex patch has been interposed between the two nitinol discs to prevent this complication. In reported series of 30 cases with this new device, it has been demonstrated that there were no recurrent shunts due to membrane perforation during $7.1 \pm 4.7$ months. ${ }^{17}$ It is more likely due to the new interposed Goretex patch, avoiding perforation of the PVA membrane. In conclusion, PVA membrane perforation is rare and serious problem that usually leads to second procedure. New Ultrasept II $^{\mathrm{TM}}$ device is promising and might change the perspective of operators. However, questions about the longterm safety of this device still remain.

\section{Limitations}

We acknowledge that there were some limitations in this study. It was a single-center and retrospective study with a small sample size. The follow-up period of patients was limited to two years.

\section{Acknowledgments}

We would like to sincerely thank Kazım Serhan Özcan that contributed to the development of manuscript.

\section{Conflict of Interest}

No conflicts of interests to disclose.

\section{Compliance of Ethical Statement}

Approval of Ethics Committee of Health Sciences University was received for the study (Ethics Committee No/Date: 18/6726.10.2018).

\section{Financial Disclosure/Funding}

The author(s) received no specific funding for this work.

\section{Author Contributions}

SB: Literature search, resources, materials; SB, HP: Critical revision, data collection, acqusation of resources, materials, Data analysis and interpretation, Manuscript drafting/writing/editing, Project development

\section{References}

1. Du ZD, Hijazi ZM, Kleinman CS. The amplatzer investigators. Comparison between transcatheter and surgical closure of secundum atrial septal defect in children and adults: results of a multicenter nonrandomized trial. $J \mathrm{Am}$ Coll Cardiol. 2002;39:1836-1844.

2. Visconti KJ, Bichell DP, Jonas RA, et al. Developmental outcome after surgical versus interventional closure of secundum atrial septal defect in children. Circulation. 1999;100(Suppl):II145-II150.

3. King TD, Thompson SL, Steiner C, et al. Secundum atrial septal defect: non operative closure during cardiac catheterization. $J$ Am Med Assoc. 1976;235:2506-2509.

4. Alexandre N, Ribeiro J, Gärtner A, et al. Biocompatibility and hemocompatibility of polyvinyl alcohol hydrogel used for vascular graftingIn vitro and in vivo studies. J Biomed Mater Res Part A. 2014;102(12):42624275. doi:10.1002/jbm.a.35098.

5. Huang Y, Kong JF, Venkatraman SS. Biomaterials and design in occlusion devices for cardiac defects: A review. Acta Biomater. 2014;10:1088-1101. doi:10.1016/j.actbio.2013.12.003.

6. Nassif M, Abdelghani M, Bouma BJ, et al. (2016):Historical developments of atrial septal defect closure devices: what we learn from the past. Expert review of medical devices. 2016; 13(6):555-568. doi:10.1080/17434440.2016.1182860.

7. Bartel T, Bonaros N, Muller S. Device failure weeks to monthsafter transcatheter closure of secundum type atrial septal defects. Heart. 2010;96:1603. doi:10.1136/hrt.2009.185942.

8. Bhattacharyya S, Ilsley CD, Baltabaeva A. Disintegration of polyvinyl alcohol membrane covering atrial septal defect closure device. Eur Heart J Cardiovasc Imaging. 2015;16:1153. doi:10.1093/ehjci/jev163.

9. Labombarda F, Roule V, Beygui F. Delayed spontaneous perforation of polyvinyl alcohol membrane-covered atrial septal defect closure devices. Catheter Cardiovasc Interv. 2017;89(4):E141-E144. doi: 10.1002/ccd.26704.

10. Ramoglu MG, Ucar T, Tutar E. Early malfunction of polyvinyl alcohol membrane of septal occluder. Catheter Cardiovasc Interv. 2016;87:E151153. doi:10.1002/ccd.26057.

11. Chamié F, Maia J, Giuliano LC. Device-in-device: A transcatheter alternative to surgical explantation of a failing atrial septal defect intracardiac prosthesis. Catheter Cardiovasc Interv. 2016;88(2):239-243. doi:10.1002/ccd.26456.

12. Bozyel S, Şahin T, Dervis E, et al. A massive left-to-right shunt due to delayed spontaneous perforation of polyvinyl alcohol membrane of atrial septal occluder. Turk Kardiyol Dern Ars. 2017;45(6):541-544. doi:10.5543/tkda.2017.04640

13. Rosa SA, Ferreira F, Sousa L, et al. Successful percutaneous closure of a residual atrial septal defect due to device failure. Rev Port Cardiol. 2017;36(6):475.e1-475.e3. doi:10.1016/j.repc.2016.09.020.

14. Bozyel S, Sahin T. Residual shunt due to spontaneous perforation of polyvinyl alcohol membraneof ASD Occluder; what about after diagnosis? Rev Port Cardiol. 2018;37(7):631. doi:10.1016/j.repc.2017.11.012.

15. Chen $F$, Zhao $X$, Zheng $X$, et al. Incomplete endothelialization and late dislocation after implantation of an Amplatzer septal occluder device. Circulation. doi:10.1161/CIRCULATIONAHA.110.991836.

16. Vogt MO, Kühn A, Hörer J, et al. Clinical, echocardiographic and histopathologic findings in nine patients with surgically explanted ASD/PFO devices: do we know enough about the healing process in humans? Int $J \quad$ Cardiol. 2011;147(3):398-404. doi:10.1016/j.ijcard.2009.09.544.

17. Roberto M-V, Antonio G-MJ, Elena S-LM, et al. Atrial septal defect closure with the new Cardia Ultrasept II ${ }^{\mathrm{TM}}$ device with interposed Goretex patch: Mexican experience - as the perforation of Ivalon's membrane been solved? Cardiol Young. 2018;28(5):709-714. doi:10.1017/S1047951118000100. 